\title{
RODZAJE SYSTEMÓW RATOWNICTWA W POLSCE - HISTORIA I TERAŹNIEJSZOŚĆ
}

\section{TYPES OF RESCUE SYSTEMS IN POLAND - HISTORY AND PRESENT}

\author{
Ewelina Kimszal, Justyna Sarosiek \\ student studiów doktoranckich, Zakład Zintegrowanej Opieki Medycznej, Wydział Nauk o Zdrowiu, Uniwersytet Medyczny w Białymstoku \\ DOI: https://doi.org/10.20883/ppnoz.2019.33
}

\begin{abstract}
STRESZCZENIE
Rozwój komunikacji samochodowej, kolejowej i lotniczej, wprowadzanie nowych technik przemysłowych i budowlanych, pojawiające się napięcia w stosunkach międzynarodowych, globalne zagrożenie atakami terroru, narastające zagrożenie katastrofami wywoływanymi przez siły natury powodowane przez ludzi stawiają coraz wyższe wymagania systemom i służbom ratowniczym na całym świecie. Dokładne poznanie historii i metod pomocy poszkodowanym pozwoli lepiej poznać poszczególne systemy ratownictwa.

Słowa kluczowe: ratownictwo, rodzaje ratownictwa, pomoc, poszkodowani.

ABSTRACT

The development of car, rail and air transport, the introduction of new industrial and construction techniques, emerging tensions in international relations, the global threat of terror attacks, the growing threat of disasters caused by forces of nature or caused by people put higher and higher demands on rescue systems and services around the world. A thorough knowledge of the history and methods of assistance to the victims will allow us to better understand the individual rescue systems.
\end{abstract}

Keywords: rescue, types of rescue, help, injured.

\section{Wstęp}

W związku z rosnącym tempem życia i ekspansją człowieka na różne dziedziny wzrasta zagrożenie życia ludzi. Potrzeba pomagania poszkodowanym spowodowała powstanie wielu służb ratowniczych. Działalność ratownicza została obwarowana przepisami prawnymi regulującymi wyposażenie służb oraz sposób ich działania. Wszystkie systemy ratownictwa mają na celu ratowanie życia ludzkiego i niesienie pomocy w warunkach zagrożenia, a także ratowanie lub zabezpieczanie sprzętu i pomieszczeń.

\section{Polskie ratownictwo górskie}

Historia ratownictwa górskiego w Polsce sięga czasów wcześniejszych niż data założenia pierwszej polskiej organizacji ratowniczej, istniejącej do dziś: Tatrzańskiego Ochotniczego Pogotowia Ratunkowego. Sześćdziesiąt lat przed oficjalnym rozpoczęciem działalności TOPR istniały już zapiski o śmierci ludzi, którzy zostali zasypani przez lawinę, lub odnalezieni nieżywi w górach, a takie wypadki musiały zdarzać się jeszcze wcześniej. Pierwszą znaną ofiarą, jaką pochłonęły Tatry, był poszukiwacz skarbów, który nazywał się Papirus. Ciało jego odnaleziono w roku 1771 [1]. Opowieści, przekazywane były później ku przestrodze następnym pokoleniom zakopiańskich górali, którzy zajmowali się wypasem bydła na halach. Ze względu na strach przed śmiercią zimą górale nie wchodzili w wyższe partie gór. Z czasem zaczął wykształcać się zawód przewodnika, który polegał na przeprowadzeniu latem turystów w wysokie części Tatr. Najczęściej rekrutowali się do tego zajęcia koziarze i świszczarze, którzy polowali (w niedostępnych dla zdecydowanej większości ówczesnych turystów) wysokich partiach gór na kozice i świstaki [2].

Koniec dziewiętnastego wieku to szybki rozwójturystyki i taternictwa po obu stronach Tatr: po polskiej i spiskiej. Górale, którzy stali się przewodnikami, byli poważanymi osobami wśród turystów. Towłaśnie onimieliniezbędną wiedzę o topografii terenu, potrafilizwinnie poruszaćsięwśród skał, a możliwość zarobku dzięki turystom napływającym w strony górskie z nizin traktowali bardzo poważnie. Opieka nad przybyszami sprawowana była profesjonalnie i niezwykle odpowiedzialnie - przewodnik taki zabawiał, nosił jedzenie i nierzadko ciężki ekwipunek, a nieraz pomagał poszkodowanym wydostać się ze szczelin lub chronił przed spadającym głazem [3].

W 1877 r. Towarzystwo Tatrzańskie wprowadziło podział na trzy klasy zawodowe przewodników, którzy mogli prowadzić turystów na wyznaczone szczyty [4]. Górale 
szybko wypromowani weszli w nową rolę społeczną. Początkowo przewodnictwo było dla niech tylko elementem w dotychczasowym sposobie życia, jednak z czasem stało się dla wielu pasjonującą pracą. Wykształciła się specyficzna "etykazawodowa" górali, którzy stali się przewodnikami, którzy podchodzili rzetelnie do swojej pracy. Odwaga, męstwo, dbałość o bezpieczeństwo gości, wytrwałość i wielki spokój, z którymi podchodzili do trudności pokonywanych tras budzą do dnia dzisiejzzego podziw wielu ludzi. Obraz dawnych czasów maluje na kartach swej książki Mariusz Zaruski. Gotowość do poświęcenia własnego zdrowia oraz życia wymagała od przewodników podporządkowania się ważnej idei: być ofiarnym wobec drugiego człowieka, z którym nie łączą żadne więzi rodowe.

Zakopane z czasem stawało się coraz popularniejszym uzdrowiskiem i letniskiem dla wielu osób. Górale mieli coraz większy kontakt z nowymi osobami, które były chętne do wypraw w góry. Coraz odważniejsze wspinaczki wymagały doskonałej kondycji fizycznej, umiejętności przewidywania i szybkiego odnalezienia się $w$ roli gospodarzy. Niepisane zasady przekazywane $z$ ust do ust i realizowane każdego dnia. Znalazły pochwałę również w lokalnej prasie [5]. Przegląd Zakopiański publikował również informacje na temat przewodników także, kiedy informował o wypadkach w górach. Gazeta ta zresztą często na bieżąco poruszała kwestie społeczne i publikowała głosy w sprawie przyszłości turystyki tatrzańskiej [6].

Koniec XIX i pierwsze dziesięciolecie XX wieku związane były nie tylko z zaborami, ale także z rozwojem alpini$z m u$, a wielu taterników wracało $w$ tym czasie zza granicy. W Alpach spotkali się z zimowymi wyjściami w góry na nartach, co w Polsce w tamtym czasie nie było w ogóle znaną dyscypliną - zimą góry stawały się dla naszych rodaków niedostępne, a wyprawy groziły utratą życia. Wszyscy taternicy i przewodnicy natomiast doskonale radzili już sobie z letnimi wycieczkami pieszymi. Jednak życie na pograniczu epok związane było z ciągłym dostosowywaniem. Środowisko górali zakopiańskich było $\mathrm{w}$ tamtych czasach dość zamknięte. Tworzenie się nowej grupy zawodowej związane było ze strukturami rodowymi: epoka przednowoczesna wspótistniała ze strukturą nowoczesną. Tradycje i silne więzi wewnątrzgrupowe sprawiły, że jednostki wywodzące się stamtąd miały wielką siłę woli, ambicję i przywiązanie do obyczajów ludowych. Wstęp do genealogii rodu Bachledów w Zakopanem przedstawia wprost tę sytuację na przykładzie dwóch rodów.

Gąsieniców można scharakteryzować jako dojrzałą wspólnotę rodową z aspiracjami przywódczymi, zaś Bachledowie szczycą się ludźmi ambitni, umiejącymi wybić się na przeróżnych płaszczyznach życia społecznego [7].
Najlepsi przewodnicy tamtych czasów po polskiej stronie są to osoby wzorowo wypełniające swoje obowiązki: w większości byli to członkowie góralskich rodów. Wymienia się tutaj: Józefa Wawrytkę, Szymona Tatara, Macieja Sieczkę, Jędrzeja Walę, Wojciecha Roja, Klimeka Bachledę, Wojciecha Tylka Suleję. Pod ich czujną opieką zdobywal szczyty inni znamienici ludzie, tacy jak ksiądz Józef Stolarczyk - pierwszy polski zdobywca Gierlachu; dr Tytus Chałubiński i jego syn Ludwik Chałubiński, Janusz Chmielowsk - pierwszy zdobywca wielu tatrzańskich szczytów, w tym Gierlacha w warunkach zimowych.

Pomiędzy przewodnikiem a "klientem" musiało być wielkie zaufanie: budowało trwały kapitał społeczny i tworzyło przestrzeń do wymiany poglądów. Również wymiany nauki i „socjalizacji” przyjezdnych do warunków górskich. Zaufanie powstawało na podstawie kontaktów społecznych turystów z innymi ludźmi, którzy korzystali z usług przewodników oraz polecali kolejnym najlepszych opiekunów. W ten sposób utworzyła się zgrana sieć społecznych interakcji, obejmująca z z roku na rok większe grono jednostek oraz całych grup społecznych - środowisko zakopiańskich górali, taterników oraz grupy koleżeńskie i zawodowe. Utworzyły się silne więzi między współpracownikami, często na całe życie i sięgały nieraz one kolejnych pokoleń. Najsilniejsze jednostki korzystały z rosnącego kapitału społecznego, rozwijając swoją działalność górską, przy czym wybierali partnerów wśród najlepszych przewodników, a późniejszych ratowników pierwszego pogotowia górskiego w Polsce [7].

Połączenie kapitału społecznego (kontaktów, więzi, znajomości) z kapitałem ekonomicznym i kulturowym (tradycja góralska, specyficzny charakter, jaki mieli górale oraz zamiłowanie do wolności) pozwoliło wykształcić jednostk gotowe często do wielkich poświęceń. Dlatego nie dziwi "góralomania" obecna w Polsce aż do II wojny światowej, opisana przez państwa Paryskich w Wielkiej Encyklopedii Tatrzańskiej. Powszechne mniemanie, że Górale mają wyłącznie cechy dodatnie, potęgowane było przez licznie publikowane dzieła Tytusa Chałubińskiego, a potwierdzane w książkach Bronisława Rajchmana i Stanisława Witkiewicza. Często kosztowne wyprawy „bez programu” organizowane przez Tytusa Chałubińskiego z udziałem jego najlepszych przyjaciół i znakomitych przewodników w romantycznym duchu, zawsze z muzyką i śpiewami góralskimi odbijały się echem w całym kraju. Choć wycieczki te nie miały wtedy żadnego wpływu na rozwój taternictwa, a często były nawet ostro krytykowane i wyśmiewane przez część ówczesnych taterników, pozwoliły one na zmianę na lepszy wizerunku Zakopanego w oczach odwiedzających letników [1]. 


\section{Wodne Ochotnicze Pogotowie Ratunkowe}

Wodne Ochotnicze Pogotowie Ratunkowe jest to specjalistyczne stowarzyszenie o zasięgu ogólnokrajowym, które zajmuje się wykonywaniem zadań związanych z ratownictwem wodnym. Jest ważną organizacją pozarządową z celami statutowymi: organizowanie pomocy oraz ratowanie osób, które uległy wypadkowi lub bezpośrednio narażone są na niebezpieczeństwo utraty życia lub zdrowia na wodzie. Misją przewodnią WOPR jest działanie na obszarze naszego kraju na rzecz pomniejszania liczby osób tonących w wodach polskich [9].

Najstarszy zapis źródłowy znaleziony został w zorganizowanej formie ratownictwa wodnego na ziemiach polskich i pochodzi z 1604 r. Hieronim Gostomski ufundował wówczas w Sandomierzu klasztor i szpitalik. Mieszkający tam zakonnicy musieli między innymi nieść pomocy ofiarom Wisły. W 1775 roku z inicjatywy księdza Adama Czartoryskiego wydano $\mathrm{w}$ stolicy pierwszą w języku polskim broszurę o ratowaniu ludzi. Wraz z końcem XVIII wieku powołano w Krakowie Pogotowie Ratunkowe dla Tonących, natomiast w 1820 r. we Lwowie wydano książkę pod tytułem „Nauka i sztuka pływania”, w której autor, Karol Hojnic, opisał między innymi metody holowania ratowanych. W 1839 roku na terenie Królestwa Polskiego wydano przepisy, które dopuściły stosowanie resuscytacji [10].

W 1898 roku Zarząd Główny Carskiego Rosyjskiego Towarzystwa Ratowania Tonących w Petersburgu wyraził zgodę na utworzenie Okręgu Kaliskiego, a wraz z początkiem 1908 roku w Warszawie rozpoczęło działalność Petersburskie Towarzystwo Ratowania Tonących. W Polskim Związku Pływackim w 1926 r. powołał Komisję (później referat) do spraw Ratownictwa Wodnego z siedzibą w Siemianowicach. Komisja ta w 1927 roku ogłosiła dzień 29 czerwca Dniem Ratownika Wodnego.

W 1952 roku ratownictwo wodne weszło do programów szkolenia WarszawskiejWyższejUczelni Wychowania Fizycznego, a później do programów nauczania wszystkich uczelni wychowania fizycznego w całym kraju. Niezbędne materiały do nauki przedmiotu zebrał i opracował prof. $\mathrm{dr}$ hab. Mieczysław Witkowski, który rozpoczął koncepcyjny rozwój ratownictwa wodnego w Polsce. W 1958 roku prof. M. Witkowski rektor Akademii Wychowania Fizycznego w Warszawie rozpoczął publikowanie z zakresu ratownictwa wodnego [11].

W kilkusetletnią tradycję ratownictwa wodnego w Polsce wpisuje się Wodne Ochotnicze Pogotowie Ratunkowe w latach 1987-90, realizujące misję działania na rzecz pomniejszania liczby osób tonących w narodowych wodach. Towarzystwo to zostało powołane zaraz po wydaniu zarządzenia nr 74 Przewodniczącego Głównego Komitetu Kultury
Fizycznej i Turystyki z dnia 11 kwietnia 1962 roku jako specjalistyczne stowarzyszenie o zasięgu ogólnokrajowym, które działa na obszarze Rzeczypospolitej Polskiej.

Od 1971 roku wodne ochotnicze pogotowie ratunkowe jest członkiem Międzynarodowej Federacji Ratownictwa Wodnego (FIS). Podczas połączonego kongresu Word Life Saving i FIS w 1994 roku, który odbył się w Cardiff, utworzono jedną międzynarodową federację ratownictwa wodnego o nazwie International Life Saving Federation.

Wodne ochotnicze pogotowie ratunkowe posiada w swoich zespołach ponad 75 tysięcy członków, wielu po przeszkoleniu uzyskuje stopnie: młodszego ratownika WOPR, ratownika WOPR oraz ratownika wodnego pływalni, śródlądowego lub morskiego, a następnie starszego ratownika wodnego. Kadra dydaktyczna składa się ze szczebli: młodszego instruktora, instruktora WOPR, instruktora-wykładowcy WOPR. Od wielu lat działa Rada Naukowa WOPR, obecnie z trzydziestoma siedmioma pracownikami naukowymi. W skład wchodził prorektor prof. dr hab. Zbigniew Dziubiński i kierownik Zakładu Pływania i Ratownictwa dr hab. Zdzisław Szwarc oraz z oddziałem AWF w Białej Podlaskiej dr Florian Parnicki. Ważną rolę odgrywa wieloletni kierownik centralnych kursów przygotowujących do egzaminów na stopnie starszych ratowników wodnych dr Paweł Różański i instruktor centralnych szkoleń WOPR dr Piotr Siłakiewicz. Kadra naukowa i dydaktyczna oddziału Akademii Wychowania Fizycznego w Białej Podlaskiej wyszkoliła setki ratowników WOPR.

Od początku powstania stowarzyszenia prowadzi ono akcje profilaktyczne z nauką pływania, organizuje również zawody sportowe nad Bałtykiem oraz w pływalniach, w tym Mistrzostwa Polski i cykl zawodów Grand Prix w Ratownictwie Wodnym. Reprezentanci Polski wielokrotnie zostawali mistrzami świata i Europy w ratownictwie wodnym, a najwybitniejszymi zawodnikami byli Wojciech Blechar oraz Zofia i Jacek Krawczykowie, którzy obecnie są pracownikami dydaktycznymi Akademii Fizycznej w Warszawie.

\section{Główne cele statutowe stowarzyszenia ratowników wodnych realizowane są między innymi poprzez:}

- $\quad$ prowadzenie akcji ratowniczych podczas zagrożeń powszechnych, katastrof naturalnych $i$ awarii technicznych, takich jak powodzie i pożary wodne;

- przeprowadzenie profilaktycznej działalności w zakresie bezpieczeństwa osób na wodach;

- wydawanie ekspertyz i opinii z zakresu bezpieczeństwa wodnego; 
- organizowanie szkoleń dla służb ratowniczych, z nadawaniem stopni ratownikom wodnym i określaniem ich uprawnień;

- nauczanie pływania dla chętnych [10]

\section{Centrum Powiadamiania Ratunkowego}

Formalna nazwa Centrum Powiadamiania Ratunkowego (CPR) pojawiła się w grudniu 1999 roku w nowelizacji rozporządzenia Ministra Spraw Wewnętrznych i Administracji w sprawie szczegółowej organizacji krajowego systemu ratowniczo-gaśniczego (KSRG). Za podstawowy element systemu, który przyjmuje informacje o zdarzeniach alarmowych, uznano wówczas stanowiska kierowania w komendach Państwowej Straży Pożarnej. Struktury te miały na celu dokonywać „bieżącej wymiany informacji niezbędnej do prognozowania zagrożeń i prowadzenia działań ratowniczych oraz stanowić centrum powiadamiania ratunkowego sił i środków podmiotów systemu lub wspomagających system" (Dz.U. z 1999 r. Nr 111 poz. 1311).

Zgodnie z założeniami koncepcji do zadań SPR należy między innymi:

- przyjęcie/selekcja zgłoszenia o nagłym zagrożeniu życia, zdrowia, środowiska bądź mienia,

- dysponowanie sił i środków służb ratowniczych i podmiotów z nimi współdziałających,

- wspomaganie kierującego działaniem ratowniczym,

- analizowanie możliwości szpitalnych oddziałów ratunkowych i innych jednostek organizacyjnych szpitali [12].

Obowiązek uruchomienia numeru alarmowego 112 zleciła wszystkim krajom członkowskim Unia Europejska. Dyrektywę Parlamentu Europejskiego z dnia 7 marca 2002 roku wprowadzono, aby „użytkownicy byli w stanie wywołać jeden europejski numer alarmowy 112 oraz wszelkie inne krajowe alarmowe numery telefoniczne, bezpłatnie, $z$ dowolnego telefonu, włączając publiczne automaty telefoniczne, bez korzystania z jakiejkolwiek formy płatności". Zgodnie z wytycznymi wszystkie kraje Unii Europejskiej mają w obowiązku wprowadzić regulacje w życie do lipca 2003 roku, a państwa nowo przyjęte do dnia 1 maja 2004 roku [13].

Zmiany kolejne wprowadziło Rozporządzenie Ministra Spraw Wewnętrznych i Administracji z dnia 31 lipca 2009 roku dotyczące organizacji i funkcjonowania Centrów Powiadamiania Ratunkowego i Wojewódzkich Centrów Powiadamiania Ratunkowego (Dz.U. z 2009 r. $\mathrm{Nr} 130$ poz. 1073). Miały one działać zgodnie z dokumentami funkcjonowania Centrów Powiadamiania Ratunkowego i Wojewódzkich Centrów Powiadamiania Ratunkowego. Te dwie struktury wykonywały zadania odnoszące się do systemu powiadamiania ratunkowego, integrując KSRG i system PRM, obejmując zakres bieżącej analizy zasobów ratowniczych oraz kwalifikacji i przyjmowania zgłoszeń alarmowych i obsługi numeru 112, które inicjują procedury reagowania i powiadamiania oddziałów ratunkowych oraz jednostek organizacyjnych szpitali wyspecjalizowanych o zdarzeniach szpitalnych.

Tabela 1. Informacje uzyskiwane przez operatora numeru alarmowego z PLI [12]

\begin{tabular}{|c|c|}
\hline Rodzaj urządzenia & Uzyskiwanie informacji \\
\hline $\begin{array}{l}\text { Urządzenie zarejestrowane } \\
\text { na osobę fizyczną }\end{array}$ & $\begin{array}{l}\text { - numer zakończenia sieci, } \\
\text { z którego następuje } \\
\text { telefonowanie, } \\
\text { - imię i nazwisko osoby } \\
\text { dzwoniącej, która podpisała } \\
\text { umowę, } \\
\text { - adres zakończenia sieci, } \\
\text { z którego następuje } \\
\text { telefonowanie }\end{array}$ \\
\hline $\begin{array}{l}\text { Urządzenie zarejestrowane } \\
\text { na podmiot gospodarczy }\end{array}$ & $\begin{array}{l}\text { - } \text { numer zakończenia sieci, } \\
\text { z którego następuje } \\
\text { telefonowanie, } \\
\text { - } \text { nazwę podmiotu } \\
\text { gospodarczego, na który } \\
\text { została podpisana } \\
\text { umowa o świadczenie } \\
\text { usługi } \\
\text { telekomunikacyjnej, } \\
\text { - } \text { adres zakończenia sieci, } \\
\text { z którego następuje } \\
\text { telefonowanie (bez } \\
\text { wskazania pomieszczenia } \\
\text { lub numeru wewnętrznego) }\end{array}$ \\
\hline $\begin{array}{l}\text { ogólnie dostępny } \\
\text { „aparat publiczny” }\end{array}$ & $\begin{array}{l}\text { - } \quad \text { numer zakończenia sieci, } \\
\text { z którego następuje } \\
\text { telefonowanie, } \\
\text { - } \quad \text { adres, pod którym znajduje } \\
\text { się telefon }\end{array}$ \\
\hline $\begin{array}{l}\text { ruchomej publicznej sieci } \\
\text { telefonicznej lub sieci } \\
\text { przedpłaconej }\end{array}$ & $\begin{array}{l}\text { - } \quad \text { numer zakończenia sieci, } \\
\text { z którego następuje } \\
\text { wywołanie, } \\
\text { - } \\
\text { imię i nazwisko osoby, która } \\
\text { podpisała umowę o } \\
\text { świadczenie usługi } \\
\text { telekomunikacyjnej, } \\
\text { - } \quad \text { lokalizację geograficzną } \\
\text { aparatu komórkowego }\end{array}$ \\
\hline $\begin{array}{l}\text { Nie zarejestrowane } \\
\text { ruchomej } \\
\text { publicznej sieci } \\
\text { telefonicznej } \\
\text { („pre paid” na tzw. kartę) }\end{array}$ & $\begin{array}{l}\text { - } \quad \text { numer zakończenia sieci, } \\
\text { z którego występuje } \\
\text { wywołanie; } \\
\text { - } \quad \text { lokalizacja geograficzna } \\
\text { aparatu komórkowego, } \\
\text { z którego występuje } \\
\text { wywołanie }\end{array}$ \\
\hline $\begin{array}{l}\text { Nierozpoznane, bez IMEI } \\
\text { lub numer techniczny sieci } \\
\text { inicjującej wywołanie karty } \\
\text { SIM }\end{array}$ & $\begin{array}{l}\text { - lokalizacja geograficzna } \\
\text { aparatu komórkowego, } \\
\text { z którego występuje } \\
\text { wywołanie }\end{array}$ \\
\hline
\end{tabular}


Aktualnie podstawą funkcjonowania SPR w Polsce są przede wszystkim ustawa z dnia 22 listopada 2013 roku o systemie powiadamiania ratunkowego (Dz.U. z 2013 r. poz. 1635), a także rozporządzenie w sprawach organizacji i funkcjonowania Centrów Powiadamiania Ratunkowego, weszło one w życie z dniem 28 kwietnia 2014 r. (Dz.U. z 2014 r. poz. 574). Pierwszym dokumentem określającym główne zadania oraz zasady działania systemu, źródła tego finansowania, a także organy właściwe w sprawach powiadamiania ratunkowego. Akt wykonawczy opisywał natomiast organizację CPR, także kryteria tworzenia tych oddziałów, sposób jego funkcjonowania i realizację zadań. Określane są procedury obsługi zgłoszeń alarmowych wraz ze wskazaniem liczby operatorów numerów alarmowych wraz ze sposobem jej podziałów na poszczególne centra. Przede wszystkim uregulowany jest tu jednolity sposób obsługi zgłoszenia alarmowego, a także rozmowy ze zgłaszającym [12].

Głównym celem Systemu Powiadamiania Ratunkowego (SPR) jest poprawa bezpieczeństwa obywateli dzięki uzyskaniu szybkiego i skutecznego dostępu do służb, które są odpowiedzialne za niesienie pomocy. Wszystkie zgłoszenia alarmowe obsługiwane są według takich samych standardów. Wykonywane są przez wyszkolonych operatorów, którzy pracują w odpowiednio wyposażonych centrach. Zasięg numeru alarmowego 112 obejmuje $w$ tej chwili obszar całego kraju. Podsumowując rozdział, należy stwierdzić, że obecnie SPR skutecznie i właściwie wywiązuje się z postawionych przed nim zadań [14].

\section{Polski Czerwony Krzyż}

Czerwony Krzyżznanyjestnaświecie, ale równieżwspaniale w naszym kraju, a zrodził się z idei członków, którzy chcieli nieść pomoc drugiemu człowiekowi. $W$ drugiej połowie XIX wieku zaszło wiele wydarzeń politycznych, wojennych, obfitujących w ogromną liczbą dramatów ludzkich. Największa bitwa w ówczesnej Europie pod Solferino, zakończona klęską armii austriackiej, datowana jest na 24 czerwca 1859 roku. Przesądziła ona o losach wojny austriacko-francuskiej [16, 17].

Obserwatorem opisywanej bitwy był Henry Duant uważany za społecznika i filantropa. Z przerażeniem spoglądał on na konających żołnierzy walczących armii. Uwagę zwrócił on na brak dostatecznej, a również na słabo zorganizowaną opiekę sanitarno-medyczną. H. Duant postanowił więc opisać okrucieństwa, jakie niosła za sobą wojna i zainteresować innych, przede wszystkim elity ówczesnej Europy. W książce pod tytułem „Wspomnienie Solferino" z 1862 roku przedstawił on również możliwości organizacyjne ratowania rannych [18]. Propagował w niej propozycje humanitarnej działalności. Udało mu się uzyskać poparcie jak również aktywną pomoc zwolenników i doprowadzić do powołania Komitetu Pięciu (17 lutego 1863 roku). W jego skład wchodzili: Henry Dufour, Gustaw Moynier, Louis Appia, Theodore Maunior, Henry Dunant.

W głównych ustaleniach, jakie podjął międzynarodowy kongres w Genewie, który odbywał się w dniach 26-29 październik 1863 roku, znalazło się między innymi ustalenie konieczności wspomagania ambulansów, różnego rodzaju szpitali, personelu ochotniczego niosącego pomoc rannym, a ponad wszystko tych, co brali udział w walkach. Po tym przyjęto jedną z głównych zasad neutralności dla uczestników, którzy ratowali innych. Ustalono również jednolity znak ochronny - został nim czerwony krzyż na białym tle. Barwy te, jak mało kto wie, są odwrotnością barw flagi Szwajcarii [16, 17]. W pewnych częściach krajów muzułmańskich zamiast czerwonego krzyża użyto inny, ale pełniący równoznaczne funkcje, znak czerwonego półksiężyca. Unikając kojarzenia znaków z symboliką religijną, zaproponowano w 2005 roku przyjęcie trzeciego znaku o charakterze ochronnym i jest to tak zwany czerwony kryształ [19].

Komitet Pięciu natomiast przyjął inną nazwę: Międzynarodowy Komitet Pomocy Rannym, dnia 9 listopada 1863 roku przekształca się w Międzynarodowy Komitet Czerwonego Krzyża. Zasady działania MKCK regulują nowe umowy międzynarodowe oraz konwencje (I Humanitarna Konwencja Genewska z 1864 roku., Konwencja Haska z 1899 roku, Konwencja Genewska z 1906 roku. Konwencja Haska z 1907 roku) [20]. Po I i ll wojnie światowej ogłoszono dla społeczeństwa dnia 12 sierpnia 1949 powojenne konwencje genewskie.

Powstanie Międzynarodowego Komitetu Czerwonego Krzyża, a także uchwalenie I Humanitarnej Konwencji Genewskiej znalazło oddźwięk wśród Polaków. Powstały liczne humanitarne organizacje czerwonokrzyskie. Mimo braku jednej, zjednoczonej narodowej organizacji czerwonokrzyskiej doprowadzono do kontaktów z Międzynarodowym Komitetem Czerwonego Krzyża (MKCK) w Genewie. "Samarytanin Polski” był inicjatorem zwołania na dzień 18 stycznia 1919 roku organizacji humanitarnych na naradę. Na owej naradzie której kierownikiem była Helena Paderewska oraz szef Departamentu Sanitarnego Wojska Polskiego gen. Zdzisława Horodyński powołany do Polskiego Towarzystwa Czerwonego Krzyża (PTCK). W dniu 14 lipca 1919 roku MKCK powiadomił o przyjęciu do grona członków międzynarodowej społeczności czerwonokrzyskiej Polskiego Towarzystwa Czerwonego Krzyża [16, 17]. 1 września 1927 roku zmieniono nazwę PTCK na Polski Czerwony Krzyż, zachowując jego dotychczasowe zadania. 
Najważniejsze działania PCK to:

- pomoc socjalna,

- krwiodawstwo honorowe,

- promocja zdrowia,

- pierwsza pomoc i ratownictwo,

- udział w międzynarodowych akcjach pomocy Czerwonego Krzyża,

- pomoc cudzoziemcom,

- Biuro Informacji i Poszukiwań,

- upowszechnianie międzynarodowego prawa humanitarnego [21].

\section{Podsumowanie}

Każda dziedzina życia niesie ze sobą jakieś zagrożenia. W Polsce jest wiele świetnie wyszkolonych służb ratowniczych, a każdy z działających systemów ciągle opracowuje coraz to nowsze i lepsze systemy pomocy poszkodowanym. Warunkiem dobrej akcji ratunkowej jest odpowiednia organizacja i zgranie zespołu. Należy zawsze również przestrzegać przepisów bezpieczeństwa w celu zapobiegania wypadkom wśród pracowników.

\section{Oświadczenia}

Oświadczenie dotyczące konfliktu interesów

Autorzy deklarują brak konfliktu interesów.

\section{Źródła finansowania}

Autorzy deklarują brak źródeł finansowania.

\section{Piśmiennictwo}

1. Jagiełło M. Wołanie w górach. Wypadki i akcje ratunkowe w Tatrach. Warszawa 2002, str. 15-68.

2. Hunt James B. Travel Experience in the Formation of Leadership: John QuincyAdams, Frederick Douglass and Jane Addams. Journal of Leadership \& Organizational Studies, 2000, 7, str. 92-106

3. Lois J. Peaks and Valleys: The Gendered Emotional Culture of Edgework. Gender and Society, 1, 15, 3, str. 381-406.

4. GOPR Grupa Beskidzka. Podpisanie Ustawy przez Prezydenta. Grupa Beskidzka GOPR. 2011 [Online] [Zacytowano: 6 czerwca 2018.] http://beskidy.gopr.pl/?podpisanie-ustawyprzez-prezydenta, 359.

5. www.gopr.p I[Online] [Zacytowano: 6 czerwca 2018.]

6. Ministerstwo Spraw Wewnętrznych i Administracji [Online] [Zacytowano: 6 czerwca 2018] https://www.mswia.gov.pl/ pl/tagi/535,GOPR.html
7. Grupa Krynicka GOPR - rozmowa z Naczelnikiem. Magazyn Tu rystyki Beskidzkiej Beskidtrek. [Online] [Zacytowano: 7 czerwca 2018.] http://beskidtrek.pl/index.php/ciekawsze-artykuy/tu rystyka/192-grupa-krynicka-gopr-rozmowa-z-naczelnikiem.

8. Krzeptowska-Jasinek M, Krzeptowski-Jasinek J. Wstęp. Genealogia rodu Bachledów w Zakopanem. Zakopane 1999, Tom 1, str. 20-55.

9. Statut Wodnego Ochotniczego Pogotowia Ratunkowego, Warszawa, dnia 6 grudnia 2003, str. 1-6

10. Telak J. Stan obecny i perspektywy współpracy WOPR ze służbami „mundurowymi" Wykład dla studentów kierunku Wychowanie Fizyczne w Służbach Mundurowych na Wydziale Wychowania i Sportu w Białej Podlaskiej Akademii Wychowania Fizycznego J. Piłsudskiego w Warszawie, 30 maj 2011 roku, str. 1-4.

11. www.worp.pl [Online] [Zacytowano: 7 czerwca 2018] http:// wopr.pl/index.php?option $=$ com_docman\&task $=$ cat_view\&gid $=280 \&$ Itemid $=27$

12. Sikora-Wojtarowicz K, Nienartowicz A. Funkcjonowanie systemu powiadamiania ratunkowego w Polsce. Założenia i praktyka. Rocznik Bezpieczeństwa Międzynarodowego 2015, 9, 2, str. 220-237.

13. Dyrektywa 2002/22/WE Parlamentu Europejskiego z dnia 7 marca 2002 r. w sprawie usługi powszechnej związanych z sieciami i usługami łączności elektronicznej praw użytkowników.

14. Wałek T. System powiadamiania ratunkowego w Polsce. Założenia i praktyka. Security, Economy \& Law 2016, 1, str. 187-195.

15. Abramek Z. Powstanie i działalność Polskiego Czerwonego Krzyża 1912-1951. Polski Czerwony Krzyż Zarząd Okręgowy, Warszawa 2001, str. 28-44.

16. Abramek Z (red.). Szkoła Pielęgniarstwa Polskiego Czerwonego Krzyża w Warszawie (1929-1944). Polski Czerwony Krzyż Mazowiecki Zarząd Okręgowy, Warszawa 2003, str. 8-15.

17. Duant H. Wspomnienie Solferino. Międzynarodowy Komitet Czerwonego Krzyża, 1983, str. 10-15.

18. Przewodnik ochrony znaku czerwonego krzyża 2013, str. 3-12.

19. Cichocka Mt. Polski Czerwony Krzyż w latach 1919-2004. Szkoła Wyższa im. Pawła Włodkowica, Płock 2006, str. 1-14.

20. Krajowa Rada Młodzieżowa PCK. Historia siedmiu zasad. Ogólnopolski Obóz dla Społecznych Instruktorów Młodzieżowych PCK, Sulejów 2012, str. 1-32.

Zaakceptowano do edycji: 20.08.19 Zaakceptowano do publikacji: 26.09.19

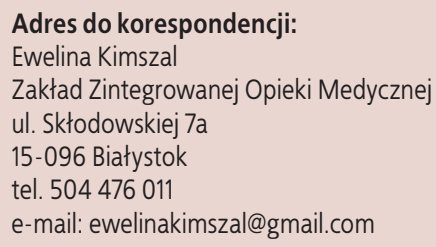

